\title{
MONETARY POLICY OF THE RUSSIAN CENTRAL BANK: RISKS AND LIMITATIONS ${ }^{1}$
}

\author{
A. Bozhechkova, A. Kiyutsevskaya, P. Trunin
}

In June, the Russian Central Bank, for the first time since summer 2015, decided to reduce the key interest rate by 0.5 percentage points, to $10.5 \%$. The decline in inflation expectations, further slowdown in inflation and stabilization of the external environment, together with the strengthening of the rouble, allowed the Bank of Russia to soften the monetary policy.

By reducing the key interest rate to $10.5 \%$, the Bank of Russia reacted to the ongoing inflation slowdown. After gradual decrease in positive growth rate of prices in January-April 2016, the inflation stabilized and accounted for $0.4 \%$ in May (0.4\% in May 2015). Moreover, during the first week of June, the consumer price index (CPI) remained unchanged. At the same time, the cumulative 12-month inflation which had been declining since September 2015 has remained unchanged at $7.3 \%$ for the past 3 months (Fig. 1). Inflation slowdown in January-April 2016 was caused by the decline in aggregate demand, as well as rouble appreciation, which reduced the pressure on domestic prices due to the exchange-rate pass-through effect.

Nevertheless, the level of inflation expectations remains high, preventing the reduction of prices in the medium term. In April 2016, the median value of expected inflation rate for the year ahead fell only by 0.1 p.p. and amounted to $14.6 \%^{2}$.

The possible recovery of consumer demand is a source of inflation risks, which ceteris paribus can lead to upward push on consumer goods prices. In Q1 2016, nominal wages of the population grew by $7.7 \%$ compared to the same period in 2015, and in April 2016, it grew by $5.4 \%$ compared to April 2015. For reference: in September-December 2015, this figure grew on average just by $3.4 \%$ in annual terms. It should also be noted that, due to the inflation slowdown, the positive growth of gross real wages was observed in February and March 2016 for the first time since September 2014. It accounted for 0.6 and $1.5 \%$, respectively, compared to the same months in 2015.

Positive contribution to $\mathrm{CPI}$ growth in 2016 can be expected from the acceleration of money supply $\mathrm{M} 2$ growth rate due to an

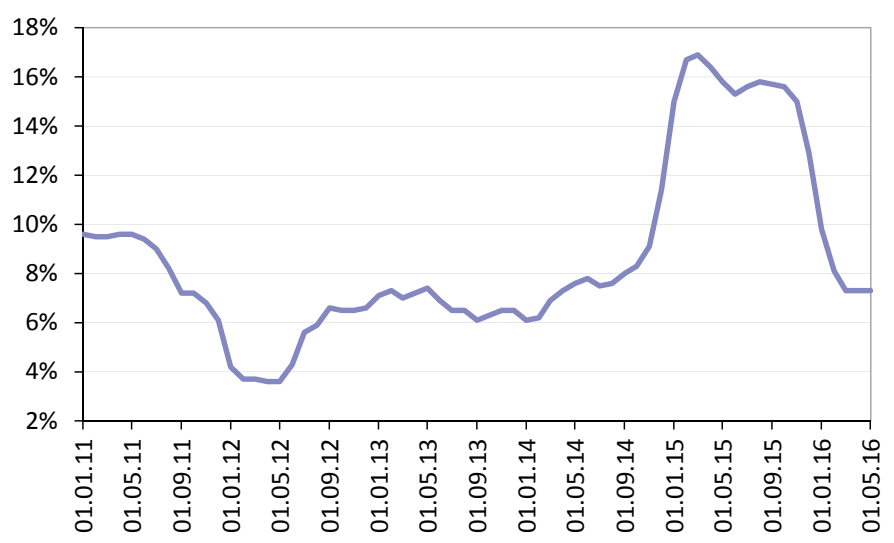

Source: Rosstat.

Fig. 1. CPI growth rate in 2011-2016 (\% of the preceding 12 month)

1 This paper was originally published in Online Monitoring of Russia's Economic Outlook No.10(28).

2 This indicator is calculated by the Russian Central Bank, see: http://www.cbr.ru/DKP/ standart_system/Infl_exp_16-04.pdf 
increase in the monetary base as the Reserve Fund money is being spent to finance the large budget deficit, as well as due to the recovery of the credit activity ${ }^{1}$. The money supply $\mathrm{M} 2$ growth rate in January-April 2016 was, on average, $10.8 \%$, while during the same period in 2015, it did not exceed $5.4 \%$ (Fig. 2).

It should be noted that the inflow of funds into the banks as money from the Reserve Fund is being spent is not fully compensated by the reduction of the banking system's debt to the Russian Central Bank. Because of this, in Q1 2016, despite

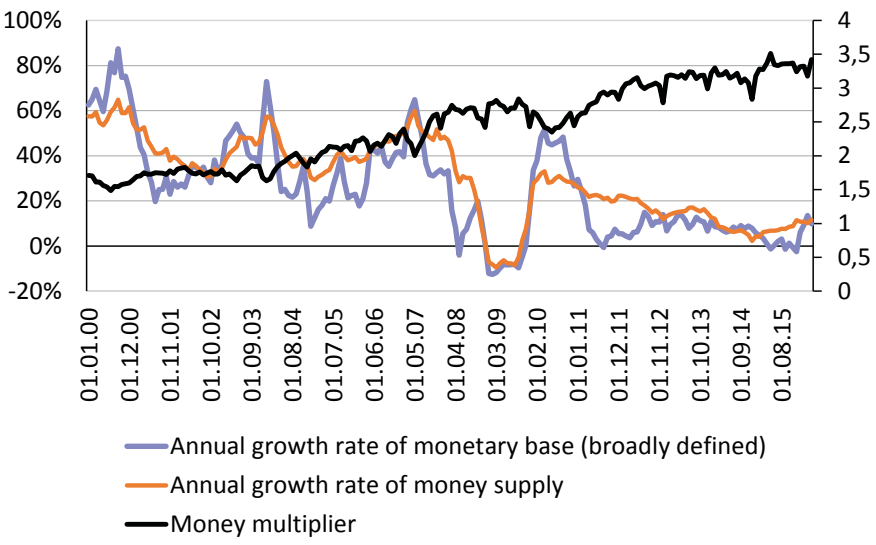

Source: Rosstat.

Fig. 2. Dynamics of monetary aggregates and money multiplier in 2000-2016

constant, interest rates were declining. In particular, interest rates on individuals' deposits of up to 1 year decreased from $8.53 \%$ per annum in January to $7.71 \%$ in March 2016. According to the Bank of Russia estimates ${ }^{2}$, in Q2 and Q3 of 2016, this trend will continue, regardless of whether the monetary policy will soften. Survey results of 56 financial institutions which own about $85 \%$ of the total loan portfolio showed that almost half of them are willing to reduce interest rates on loans.

Thus, in spite of the stabilization of the situation in the Russian economy, the Bank of Russia still faces significant internal risks impeding a more significant reduction of the key rate. To an even greater degree, however, the state of Russian financial markets depends on the dynamics of oil prices which are difficult to predict. One can remember the year 2015, when a recovery in the first half of the year was followed by a sharp decline in oil prices to new multiyear lows.

An important factor influencing the state of the global economy is the expectation of changes in the interest rate policy of the US Federal Reserve System (FRS). By postponing the raising of the key interest rate, FRS supports risk-taking behaviour of investors, causing a rise in the cost of developing countries' assets, including Russian ones. Changes in the FRS monetary policy may cause decline in the stock markets.

One can note the high sensitivity of the foreign exchange market participants to the news. For instance, the data on the US labour market released on 3 June came as a surprise as the number of those employed in the nonagriculture sector increased in May by 38 thousand people only. It is the lowest level since September 2010 when 52 thousand people were laid off. The following reaction was another weakening of the dollar on the global foreign exchange market, which supported the rise of the world prices on commodity products ${ }^{3}$. In such circumstances, they become not only reliable, but also

1 For details, see.: Sinelnikov-Murylev S.G., Trunin P.V. Government Wealth Funds and Monetary Policy in Russia // Financial Journal. 2015. No.3 (25). P. 26-34.

2 Information and Analytical Bulletin of the Bank of Russia, "Changes in bank lending conditions", 2016. No.1.

3 Since the contracts for many commodities are denominated in US dollars, the weaker dollar makes those products cheaper for buyers from outside the US, contributing to the growth of demand for them. The opposite is observed in the case of strengthening of the dollar. 
the most profitable assets. By the end of May, the price for Brent rose to 50 dollars per barrel, a week later - to 51.5 dollars.

The inevitable tightening of the FRS monetary policy together with actions of other developed countries' monetary authorities that adhere to super soft monetary policy is likely to provoke a change in the prices of financial assets and commodities worldwide. This, in turn, can lead to quicker capital outflow from Russia, the weakening of the rouble and the increase in inflation.

The situation in the Chinese economy which continues to slow down stays an important risk factor for the Russian economy in general and monetary policy in particular. The current easing of tension on the Chinese foreign exchange market is likely to be temporary. The index of business activity in the Chinese industry fell in May to 49.2 points compared to 49.4 points a month earlier. Further deterioration of the economic situation in China can lead to a new drop in energy prices. 